\title{
Introduction: A Special Section on Self-Determination and the Use of Referendums: Catalonia, Quebec and Scotland
}

\author{
Montserrat Guibernau • François Rocher • \\ Elisenda Casanas Adam
}

Published online: 4 December 2013

(C) Springer Science+Business Media New York 2013

Referendums (also known as plebiscites) are instruments to bring democracy closer to the citizens by means of a direct vote in which the entire electorate is asked to either accept or reject a particular proposal. Referendums reveal the views of the people in a direct manner and, in this respect, they epitomise "popular sovereignty". Legitimacy emanates from them. Referendums are known as a key example of direct democracy. Often, referendums are concerned with important constitutional changes aiming to transform the system of government. By submitting constitutional changes to a referendum, these changes become entrenched; this means that future governments and parliaments will only be able to reverse the changes if they consult the people in a new referendum.

However, some key questions need to be addressed: who is entitled to hold a referendum? What are the mechanisms to grant it legitimacy? And, who decides on its conditions and binding nature?

Recently, Quebec went through a referendum process twice, Scotland is about to conduct one in 2014 and Catalonia is struggling with Madrid to organise its own referendum on Catalan independence. The papers included in this special issue seek to explore whether referenda are efficient instruments in the furthering of democracy. In particular, it focuses upon the use of referendums as a tool to establish the strength of claims for self-determination within nations lacking a state of their own.

Quebec went through two referendums on sovereignty, in 1980 and 1995. In both cases, the secessionist project failed to achieve its goal. In 1995, the NO side won by a very thin margin

\footnotetext{
M. Guibernau $(\bowtie)$

Department of Politics and International Relations, Queen Mary University of London, Mile End Road, London E1 4NS, UK

e-mail: m.guibernau@qmul.ac.uk

F. Rocher

School of Political Studies, University of Ottawa, 120 University, Social Sciences Building, Room 7005, Ottawa, ON, Canada K1N 6N5

e-mail: frocher@uOttawa.ca

E. C. Adam

Edinburgh Law School, Old College, South Bridge, Edinburgh EH8 9YL, UK

e-mail: elisenda.casanas-adam@ed.ac.uk
} 
of $1.1 \%$ or 54,000 out of $4,757,509$ valid ballots. The 1980 defeat was followed, in 1982 , by the most substantial constitutional changes since the creation of the federation. This was achieved with a strong opposition of the Quebec National Assembly. In 1995, the narrow defeat of the secessionists' option forced the federal government to review its national unity strategy. The federal government opted to bring forth a reference case to the Supreme Court, thereby judicialising the political conflict. The federal government asked the Supreme Court whether a unilateral declaration of independence by Quebec, as proposed by secessionists in the case of failed negotiations on renewed partnership, would be legal. The rift between Quebec and the rest of Canada was made wider when the federal government made it clear in November 1999, through a Parliament of Canada legislation, that it would not negotiate the terms of secession if it judged that the question asked in a referendum was not clear, or if the secessionists only won by an absolute majority of the votes (50\% plus one). This new federal legislation makes it impossible, in practical terms, for Quebec to accede to independence while conforming to the Canadian constitution. The Canadian constitution imposes an amending formula that is so rigid that all negotiations towards secession are most likely to end unsuccessfully. That has had a strong an enduring impact on both, the internal political dynamic within Quebec between the secessionist and federalist political parties and on the configuration of Quebec's national identity and competing political projects.

The case of Catalonia stands in sharp contrast with those of Quebec and Scotland. According to the Constitution, Spain is a single "demos" formed by "all Spaniards"; the Catalans are regarded as a part of that single "demos" and this automatically deems any attempts to hold a referendum on self-determination in Catalonia illegal. In turn, Article 2 of the Constitution argues that "the Constitution is based upon the indissoluble unity of the Spanish nation, common and indivisible patria of all Spaniards", and Article 8 states that "the Army's mission is to guarantee the sovereignty and independence of Spain, to defend its territorial integrity and the constitutional set up".

The Barcelona 1.5 million people demonstration in favour of self-determination (11 September 2012), and the 2013 so-called "Catalan way" (a human chain which spanned Catalonia from north to south on 11 September 2013) in which a total of 1.6 million Catalans participated, illustrate the strength of the civic movement in favour of allowing Catalonia to decide upon its political future by means of a referendum on remaining a part of Spain or becoming an independent country. At the time of writing, in Catalonia support for independence has risen to $52.3 \%$ according to Spain's main radio station, Cadena Ser opinion poll on 11 September 2013.

On Spain's National Day (12 October 2013) in Barcelona, 30,000 people according to the "Guardia Urbana", 105,000 according to the Delegation of the Spanish Government and 160,000 according to the organisers, have demonstrated in favour of Spanish unity and against Catalan demands to hold a referendum on independence. In Spain, hostility against Catalan demands has been accompanied by threats to suspend Catalonia's autonomy amid accusations of sedition against Mas and his government.

With the Scottish Nationalist Party's (SNP) landslide victory in the 2011 elections to the Scottish Parliament, the people of Scotland endorsed its ongoing pledge to hold a referendum on independence for Scotland. The UK government acknowledged the SNP's significant victory and accepted that the future of Scotland's place within the Union was for the people of Scotland to vote on. In January 2012, both the UK and Scottish governments initiated separate consultations putting forward their respective options for the design of the referendum and highlighting some significant differences, most notably on the issue of whether the Scottish Parliament actually had the power to legislate for a referendum on independence under the Scotland Act 1998. 
In order to ensure the legality of the referendum and to avoid a possible challenge in the courts, the recent "Edinburgh Agreement" (15 October) between Alex Salmond and David Cameron provided for the enactment of a Section 30 order to confirm that the Scottish Parliament has the necessary power to legislate for a single question referendum, designed and run by the people of Scotland, and to be held before 31 December 2014. This agreement has been praised as an example of dialogue and conciliation, and has been described as the most significant date in Scottish history since the Union of Scotland and England in 1707. The process is now in motion; this paper focuses on the preparation and design of the referendum bill, with the aim of considering if and how the process and the terms established provide for a clear, fair, informed and deliberative decision, thus functioning effectively as a tool for democratically articulating the will of the people of Scotland. In this way, it also contributes more generally to exploring the role of referendums in cases of claims for self-determination in plurinational states. 